\title{
ZASTOSOWANIE MODELU HARDENING SOIL SMALL W ANALIZACH NUMERYCZNYCH UKŁADU RUROCIĄG-GRUNT
}

\begin{abstract}
W artykule podano podstawowe informacje, dotyczące sprężysto-plastycznych modeli gruntu, ze szczególnym uwzględnieniem modelu Hardening Soil Small (model sprężysto-plastyczny o wzmocnieniu izotropowym). Model ten zastosowano w numerycznej analizie układu rurociąg-grunt (2D), odwzorowującego podatny rurociąg (PVC), ułożony w gruncie (wariantowo: piaski, glina). Wyniki analizy przedstawiono w postaci map naprężeń w gruncie oraz wykresów uogólnionych sił wewnętrznych w rurociągu. W celu zbadania wrażliwości modelu HSS wykonano także jego analizę parametryczną (wpływ OCR).
\end{abstract}

Słowa kluczowe: MES, interakcja rura-grunt, konstytutywny model gruntu

\section{Konstytutywne modele gruntu}

\subsection{Ogólna charakterystyka modeli sprężysto-plastycznych}

Jednym z podstawowych problemów numerycznego modelowania interakcji konstrukcji z otaczającym ją gruntem (analizy deformacji i naprężenia) jest właściwe odwzorowanie jego zachowania się w trakcie działania zewnętrznych obciążeń. Skomplikowany, wielofazowy ośrodek, jakim jest niewątpliwie grunt, jest ośrodkiem trudnym do opisu, zwłaszcza z uwagi na występowanie w trakcie obciążania złożonych efektów makroskopowych takich jak plastyczność, anizotropia, pełzanie czy nieliniowość fizyczna. Pozostawiając na boku, jako mało realistyczne, modele sprężyste (liniowa zależność między naprężeniem a odkształceniem) i tzw. model Winklera (grunt reprezentowany przez układ sprężyn o określonej podatności), za szczególnie użyteczną do opisu zachowania się gruntu uznać należy grupę modeli sprężysto-plastycznych. W grupie tej lokują się modele sprężysto-idealnie plastyczne, modele sprężysto-plastyczne o wzmocnieniu izotropowym (w tym modele stanu krytycznego i modele typu „cap”) lub o wzmocnieniu kinematycznym. Modele te zostały opisane w szeregu

\footnotetext{
${ }^{1}$ Barbara Kliszczewicz, Politechnika Śląska, Katedra Geotechniki i Dróg, Wydział Budownictwa, 44-100 Gliwice, ul. Akademicka 5, tel. + 48 (32) 2372257, fax: (32) 2372873 e-mail: barbara.kliszczewicz@polsl.pl
} 
aktualnie dostępnych, przeglądowych pozycjach literaturowych $[4,6]$. Są także wbudowane $\mathrm{w}$ wielu programach komputerowych, używanych do numerycznych analiz zagadnień interakcji konstrukcji z gruntem (m. in. ANSYS, ABAQUS, PLAXIS, ZSOIL). Zatem, do wykonawcy analizy numerycznej należy decyzja dotycząca wyboru konkretnego modelu konstytutywnego.

Z uwagi na stosunkową łatwość wyznaczania wartości parametrów gruntu, niezbędnych do wprowadzenia $w$ jego numerycznym modelowaniu, do najpopularniejszych należy model sprężysto-idealnie plastyczny z kryterium zniszczenia Coulomba-Mohra. W modelu tym, wewnątrz powierzchni plastyczności grunt zachowuje się sprężyście, na jej powierzchni wykazuje cechy sprężystoplastyczne. Parametry modelu Coulomba-Mohra to moduł Younga $E\left(\mathrm{kN} / \mathrm{m}^{2}\right)$, współczynnik Poissona $v(-)$, kąt tarcia wewnętrznego $\phi\left({ }^{0}\right)$, kohezja $c\left(\mathrm{kN} / \mathrm{m}^{2}\right)$ oraz kąt dylatancji $\psi\left({ }^{0}\right)$. Dla piasków ten ostatni parametr może być, zgodnie $\mathrm{z}$ propozycją Boltona [3], powiązany $\mathrm{z}$ kątem tarcia wewnętrznego: przy $\phi \leq 30^{\circ} \psi=0^{\circ}$, zaś przy $\phi>30^{\circ} \psi=\phi-30^{\circ}$. Modele sprężysto-idealnie plastyczne uwzględniają odkształcenia trwałe i wpływ historii obciążenia tylko w strefach gruntu, w których wystąpił stan graniczny. Ponieważ sztywność gruntu jest traktowana jako stała, wynik analizy uzyskuje się szybko. Uważa się zatem, że model Coulomba-Mohra jest raczej skuteczny w analizach stanu granicznego (nośność podłoża gruntowego, stateczność zboczy i murów oporowych), natomiast wyznaczone w takim wypadku przemieszczenia nie są realistyczne.

Do grupy modeli sprężysto-plastycznych należy także model Hardening Soil, o wzmocnieniu izotropowym, zależnym od dwóch mechanizmów: objętościowego i dewiatorowego. Model ten występuje obecnie w dwóch wersjach: pierwsza - o nazwie Hardening Soil Standard, której autorem jest Schanz [7] i druga - Hardening Soil Small, wprowadzona w 2006 r. przez Benza [2]. W obu wersjach modelu Hardening Soil mechanizmy wzmocnienia są reprezentowane przez dwa oddzielne płaty hiperpowierzchni plastyczności i odrębne prawa izotropowego wzmocnienia. Model Hardening Soil Small, w stosunku do wersji Hardening Soil Standard, został rozszerzony i doprecyzowany w zakresie degradacji siecznego modułu sztywności $G_{s}$ w przedziale tzw. małych odkształceń, rzędu $10^{-6}-10^{-3}[1,8,9]$. Model ten realistycznie odwzorowuje także efekt zagęszczenia (zmniejszenie objętości porów na skutek deformacji plastycznych), wpływ historii obciążenia (efekt prekonsolidacji), plastyczne płynięcie, zależności sztywności od stanu naprężeń efektywnych (wzrost modułu sztywności wraz ze wzrostem głębokości lub poziomu naprężeń) oraz dylatancję (zmianę objętości podczas plastycznego płynięcia) $[8,9]$.

Model Hardening Soil Small zastosowany został m.in. w wielowariantowych analizach numerycznych układu rurociąg-grunt, w których różnicowano rodzaje gruntów, sztywność rurociągów oraz sytuacje obliczeniowe, np. wpływ procesów technologicznych czy wpływ podziemnej eksploatacji górniczej [5]. 


\subsection{Charakterystyka modelu Hardening Soil Small}

Hiperpowierzchnia plastyczności modeli Hardening Soil Small składa się z dwóch odrębnych, głównych hiperpłatów [8,9]. Pierwszy z nich, hiperpłat ścinania, jest hiperboloidą jednopowłokową, nawiązującą kształtem do powierzchni Coulomba-Mohra z parametrem wzmocnienia zależnym od plastycznego odkształcenia postaciowego. Drugi hiperpłat, współosiowy z osią hydrostatyczną, stanowi klasyczna nakładka modelu „cap”. Główny układ dwóch hiperpłatów uzupełnia końcówka ostrosłupa Coulomba-Mohra, spełniająca rolę cutoff. Rozszerzanie nasadki jest ekspotencjalną funkcją zagęszczania (trwałego spadku objętości). Przeciwnie jest z kurczeniem nasadki, która jest odpowiedzią na rozluźnienie. Wzrostowi odkształcenia postaciowego towarzyszy rozchylanie się powierzchni i odwrotnie. Działanie dwumechanizmowego wzmocnienia, zależnego od odkształcenia postaciowego i odkształcenia objętościowego, przedstawiono schematycznie na rysunku 1.

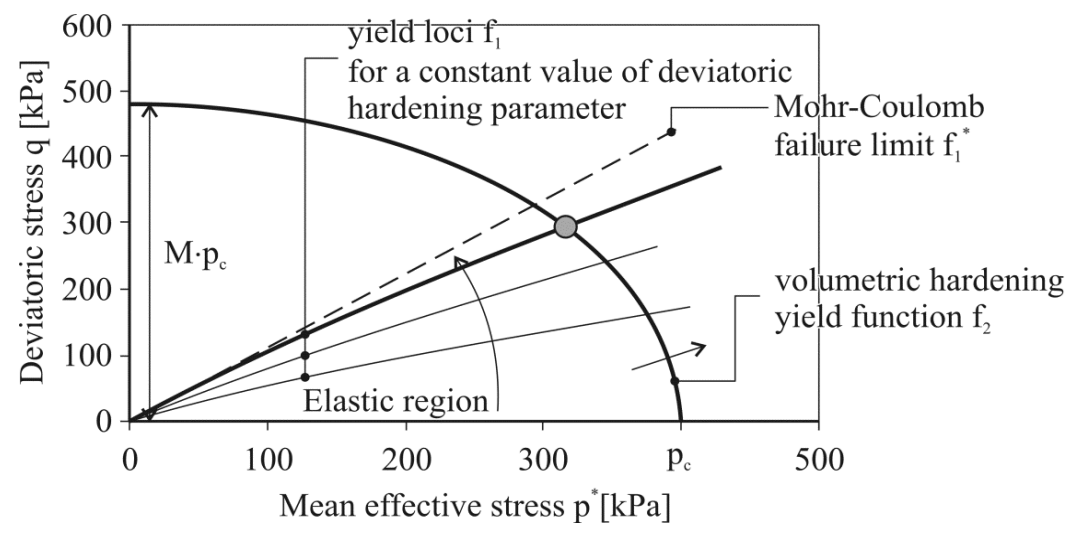

Rys. 1. Schemat działania dwumechanizmowego wzmocnienia w modelu HS Small (na podstawie $[8,9]$ )

Fig. 1. Cap surface of volumetric hardening mechanizm in HS Small model (based on $[8,9]$ )

Powierzchnię plastyczności związaną z mechanizmem ścinania (shearstrain hardening) opisuje funkcja:

$$
f_{1}=\frac{q_{a}}{E_{50}} \frac{q}{q_{a}-q}-2 \frac{q}{E_{u r}}-\gamma^{P S}=0
$$

gdzie: $\gamma^{P S}$ - parametr plastycznego wzmocnienia, kąt trwałego zniekształcenia przekroju dewiatorowego;

$q_{a}$ - asymptotyczna wartość naprężenia dewiatorowego $q_{f}$.

Graniczna wartość naprężenia dewiatorowego $q_{\mathrm{f}}$ opisana jest za pomocą kryterium Coulomba-Mohra: 


$$
q_{f}=\frac{2 \sin \phi}{1-\sin \phi}\left(\sigma_{1}+c \operatorname{ctg} \phi\right)
$$

gdzie: $\phi$ - kąt wewnętrznego tarcia gruntu;

$c$ - spójność.

Zachowanie drugiego z hiperpłatów powierzchni plastyczności, nasadki typu cap, reguluje mechanizm objętościowy (volumetric-strain hardening). Powierzchnię plastyczności opisuje w tym wypadku funkcja:

$$
f_{2}\left(\sigma^{\prime}, \varepsilon_{s}^{p l}\right)=\frac{q^{2}}{M^{2} r^{2}(\Theta)}+p^{\prime 2}+p_{c}^{2}=0
$$

gdzie: $M$ - parametr modelu HS Small, określający kształt powierzchni hiperpłata;

$r(\Theta)$ - funkcja zapewniająca gładkość i wypukłość powierzchni plastyczności (wg formuły van Eekelena).

W opisie modelu HS Small występują różne moduły sztywności: styczny moduł odkształcenia (sprężystości) $E_{0}$, sieczny moduł $E_{50}$, odpowiadający $50 \%$ wartości $q_{f}$ oraz moduł $E_{u r}$, reprezentujący nachylenie krzywej odciążenie-obciążenie. Interpretację tych modułów pokazano na rysunku 2, zawierającym charakterystykę ścinania $q-\mathcal{E}_{1}$ (gdzie $\mathcal{E}_{1}$ jest odkształceniem osiowym), aproksymowaną za pomocą hiperbolicznego prawa Duncana-Changa.

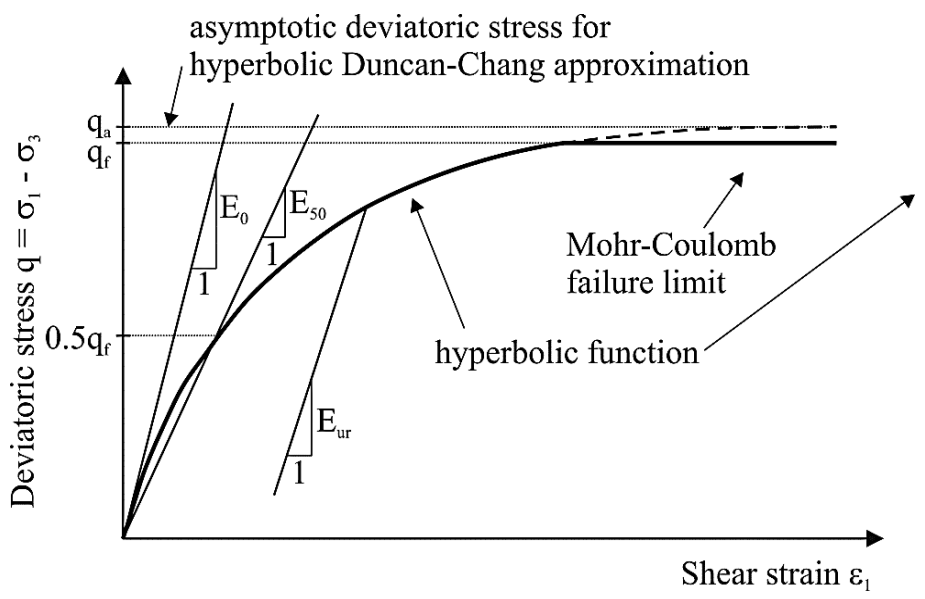

Rys. 2. Hiperboliczna zależność $q-\varepsilon_{1}$ wraz z interpretacją różnych modułów sztywności (wynik standardowego, trójosiowego testu z drenażem) (na podstawie $[8,9]$ )

Fig. 2. Hyperbolic stress-strain relationship $q-\varepsilon_{1}$ and the definitione of different stiffness modulus (result of the standard triaxal drained test) (based on $[8,9]$ ) 
Hiperboliczna zależność $q-\varepsilon_{1}$ umożliwia interpretację różnych modułów sztywności, występujących w opisie modelu HS Small. Oprócz stycznego modułu odkształcenia (sprężystości) $E_{0}$, zdefiniowano także sieczny moduł $E_{50}$, odpowiadający $50 \%$ wartości $q_{f}$ oraz moduł $E_{u r}$, reprezentujący nachylenie krzywej odciążenie - obciążenie. Dwa ostatnie moduły opisują zależności:

$$
\begin{aligned}
& E_{50}=E_{50}^{r e f}\left(\frac{\sigma_{3}^{*}+c \operatorname{ctg} \phi}{\sigma^{r e f}+c \operatorname{ctg} \phi}\right)^{m}, \\
& E_{u r}=E_{u r}^{r e f}\left(\frac{\sigma_{3}^{*}+c \operatorname{ctg} \phi}{\sigma^{r e f}+c \operatorname{ctg} \phi}\right)^{m},
\end{aligned}
$$

gdzie: $\sigma_{3}^{*}=\max \left(\sigma_{3}, \sigma_{L}\right), \sigma_{L}=10 \mathrm{kPa}, m$ przybiera wartości z przedziału $(0,3-1,0)$.

\section{Przykład analizy numerycznej układu rurociąg-grunt z zastosowaniem modelu HS Small}

\subsection{Opis modelu MES}

Przedmiotem analizy numerycznej, wykonanej w programie ZSOIL acad. ver. 11.15, jest model 2D układu rurociąg-grunt (rys. 3). Model odwzorowuje rurociąg z PVC o średnicy $\mathrm{D}=500 \mathrm{~mm}$ i grubości ścianki $s=12,3 \mathrm{~mm}$, ułożony $\mathrm{w}$ jednorodnym gruncie. Wymiary bryły gruntu (zaznaczone na rysunku 3): $a=5,0 \mathrm{~m} ; b=4,0 \mathrm{~m}$. Model obciążony jest równomiernie na fragmencie górnej powierzchni bryły gruntu (intensywność obciążenia $q=50 \mathrm{kN} / \mathrm{m}$ ).

Model składa się z 1772 czterowęzłowych elementów i 1889 węzłów. Na fragmencie górnej powierzchni modelu działa obciążenie równomiernie rozłożone. Na pionowych krawędziach modelu wprowadzone są podpory przegubowo-przesuwne, a na dolnej krawędzi modelu - podpory przegubowo-nieprzesuwne. Model ten był przedmiotem analizy, o innym niż obecnie prezentowanym zakresie, opisanej $\mathrm{w}$ referacie pt. Konstytutywne modele gruntu stosowane $w$ analizach MES interakcji rurociagów z gruntem, zamieszczonym w materiałach konferencyjnych INFRAEKO 2016.

\subsection{Parametry materiałowe}

Do modelowania składowych elementów modelu układu rurociąg-grunt użyto dwóch różnych modeli konstytutywnych.

Materiał rurociągu (PVC) modelowany jest w zakresie sprężystym (moduł sprężystości $E=4000 \mathrm{MPa}$, współczynnik Poissona $v=0,4$, ciężar objętościowy $\gamma=14 \mathrm{kN} / \mathrm{m}^{3}$ ). 


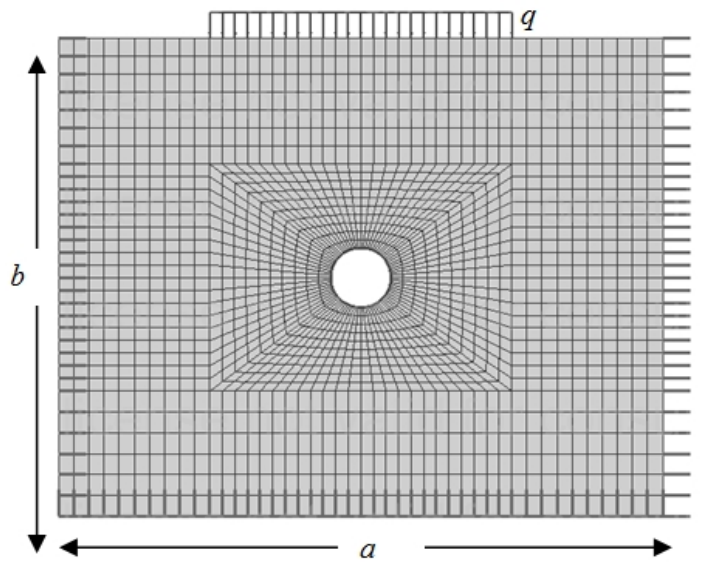

Rys. 3. Numeryczny model 2D układu rurociąg-grunt

Fig. 3. Numerical model 2D of pipeline-soil system

Grunt modelowano wariantowo, wprowadzając kolejno parametry dwóch różnych gruntów: sypkiego (piasek) i spoistego (glina). Parametry materiałowe tych gruntów wyznaczono za pomocą wbudowanego narzędzia (toolbox), które umożliwia ustalenie wartości parametrów modelu Hardening Soil Small po zadeklarowaniu charakterystycznych cech modelu, obejmujących rodzaj gruntu, historię naprężenia, zagęszczenie gruntu, uziarnienie, kształt ziaren, stan wilgotności(grunt sypki) lub historii naprężenia, stopnia plastyczności i stanu wilgotności (grunt spoisty). Poniżej zestawiono parametry gruntów, których wariantowo użyto w analizie MES opisanego powyżej układu rurociąg-grunt:

WARIANT 1 - piasek

Charakterystyka: suchy, luźny grunt, słabo uziarniony, normalnie skonsolidowany. Wartości parametrów materiałowych:

$E_{0}{ }^{r e f}=60693 \mathrm{kN} / \mathrm{m}^{2}, E_{50}{ }^{r e f}=5000 \mathrm{kN} / \mathrm{m}^{2}, E_{u r^{r e f}}{ }^{r e f} 20000 \mathrm{kN} / \mathrm{m}^{2}, E_{\text {oed }}{ }^{\text {ref }}=5000$ $\mathrm{kN} / \mathrm{m}^{2}, \gamma=15,1 \mathrm{kN} / \mathrm{m}^{3}, \phi=29,6^{0}, \psi=0,813^{0}, c=5 \mathrm{kN} / \mathrm{m}^{2}, \mathrm{OCR}=1,1$.

WARIANT 2 - glina

Charakterystyka: suchy grunt, o średniej plastyczności, normalnie skonsolidowany. Wartości parametrów materiałowych:

$E_{0}{ }^{r e f}=28103 \mathrm{kN} / \mathrm{m}^{2}, E_{50}{ }^{\text {ref }}=1625 \mathrm{kN} / \mathrm{m}^{2}, E_{u r}{ }^{r e f}=6500 \mathrm{kN} / \mathrm{m}^{2}, E_{\text {oed }}{ }^{\text {ref }}=1625$ $\mathrm{kN} / \mathrm{m}^{2}, \gamma=12,6 \mathrm{kN} / \mathrm{m}^{3}, \phi=21,5^{0}, \psi=0^{0}, c=20 \mathrm{kN} / \mathrm{m}^{2}, \mathrm{OCR}=1,1$.

\subsection{Program analizy}

Celem analizy jest przedstawienie możliwości zastosowania modelu Hardening Soil Small do badania interakcji podatnych rurociągów z gruntem. Program analizy obejmuje badanie monotonicznie narastającego obciążenia od wartości $q=0 \mathrm{kN} / \mathrm{m}(t=0)$ do wartości $q=50 \mathrm{kN} / \mathrm{m}(t=5)$ w 50 . krokach obliczeniowych (przyrost $\Delta t=0,1$ ). Wykonana analiza, o charakterze przyrostowo- 
-iteracyjnym, dotyczy obu wariantów parametrów materiałowych gruntu (piasek, glina).

W celu zbadania wrażliwości modelu Hardening Soil Small dla obu wariantów gruntu wykonano analizę parametryczną, dotyczącą wpływu współczynnika prekonsolidacji OCR, który reprezentuje historię obciążenia. Za podstawową wartość tego współczynnika przyjęto OCR $=1,1$ (oznaczenie: WARIANT 1 i WARIANT 2, grunt normalnie skonsolidowany). Dodatkowo, wykonano obliczenia dla OCR $=3,5$ (oznaczenie: WARIANT 1a i WARIANT 2a, grunt prekonsolidowany) i OCR $=7,25$ (oznaczenie: WARIANT $1 \mathrm{~b}$ i WARIANT $2 \mathrm{~b}$, grunt silnie prekonsolidowany).

\subsection{Wyniki analiz numerycznych}

Wyniki wykonanych analiz numerycznych przedstawiono w dwóch zakresach. Pierwszy z nich dotyczy naprężeń w gruncie oraz deformacji bryły gruntu i pierścienia rurowego, drugi - dotyczy wytężenia rurociągu, reprezentowanego przez obwodowe siły normalne oraz obwodowe momenty zginające.

Mapy pionowych naprężeń $w$ gruncie, wywołanych działaniem zewnętrznego obciążenia dla WARIANTÓW 1 i 2 , tj. dla OCR $=1,1(t=5,0)$ pokazano na rysunku 4.

Na podstawie map pionowych naprężeń określono ich wartości w wybranych elementach modelu, zaznaczonych na rys. 4. I tak, wartość pionowych naprężeń w elemencie 154 (górna warstwa modelu) wynosi $50,8 \mathrm{kN} / \mathrm{m}^{2}$ (piasek) i $51,0 \mathrm{kN} / \mathrm{m}^{2}$ (glina). Są to wartości odpowiadające maksymalnej wartości obciążenia $q(t=5,0)$. Wartości naprężeń pionowych wzrastają wraz z głębokością i wynoszą odpowiednio: w elemencie 818 (nad górnym punktem rury) $56,6 \mathrm{kN} / \mathrm{m}^{2}$ (piasek) i $59,3 \mathrm{kN} / \mathrm{m}^{2}$ (glina); w elemencie 1070 (dolna warstwa modelu) $79,8 \mathrm{kN} / \mathrm{m}^{2}$ (piasek) i $72,4 \mathrm{kN} / \mathrm{m}^{2}$ (glina). Układ izolinii naprężeń pionowych nie jest $\mathrm{w}$ analizowanych modelach (WARIANT 1 I WARIANT 2) jednakowy, co świadczy o zróżnicowanym charakterze interakcji analizowanego rurociągu z gruntem piaszczystym i gliniastym. Rzutuje to na charakter deformacji pierścienia rurowego i jego wytężenie.

W celu zobrazowania wpływu zmienności współczynnika prekonsolidacji OCR na deformację gruntu i rurociągu wykonano wykresy pionowych przemieszczeń dwóch charakterystycznych punktów modelu układu rurociąg-grunt. Pierwszy punkt (nr 221) jest zlokalizowany na górnej powierzchni modelu bryły gruntu, na pionowej osi symetrii. Drugi analizowany punkt (nr 894) jest usytuowany w górnym punkcie modelu rury (klucz rury). Wykresy wartości pionowych przemieszczeń punktów 221 i 894 dla różnych gruntów (piasek, glina), wyznaczonych dla kolejnych kroków analizy pokazano na rys. 5. Na rysunku tym zobrazowano także, w sposób schematyczny, położenie punktów 221 i 894.

Zarówno w wypadku punktu 221, jak i punktu 894, zmiana wartości współczynnika prekonsolidacji OCR (wzrost wartości współczynnika od 
OCR $=1,1$, przez OCR $=3,5$ do OCR $=7,25$ ) skutkuje zmniejszeniem pionowych przemieszczeń analizowanych punktów. Maksymalne wartości pionowych przemieszczeń punktu 221 wynoszą $\mathrm{w}$ wypadku gruntu piaszczystego: $0,059 \mathrm{~m}$ $(\mathrm{OCR}=1,1), 0,025 \mathrm{~m}(\mathrm{OCR}=3,5), 0,017 \mathrm{~m}(\mathrm{OCR}=7,25)$. Odpowiednio, wartości te dla gruntu gliniastego wynoszą: $0,151 \mathrm{~m}(\mathrm{OCR}=1,1), 0,066 \mathrm{~m}$ $(\mathrm{OCR}=3,5), 0,044 \mathrm{~m}(\mathrm{OCR}=7,25)$. Deformacja gruntu, spowodowana działaniem obciążenia, wywołuje deformację współpracującego z nim pierścienia rurowego. Maksymalne wartości pionowych przemieszczeń górnego punktu rury (894) wynoszą w wypadku gruntu piaszczystego: 0,024 $\mathrm{m}(\mathrm{OCR}=1,1), 0,006 \mathrm{~m}$ $(\mathrm{OCR}=3,5), 0,005 \mathrm{~m}(\mathrm{OCR}=7,25)$. Odpowiednio, wartości te dla gruntu gliniastego wynoszą: $0,058 \mathrm{~m}(\mathrm{OCR}=1,1), 0,015 \mathrm{~m}(\mathrm{OCR}=3,5), 0,013 \mathrm{~m}$ $(\mathrm{OCR}=7,25)$. Wykresy pionowych przemieszczeń we wszystkich analizowanych wariantach analizy mają charakter krzywoliniowy, zwłaszcza w początkowym zakresie obciążania.

a)

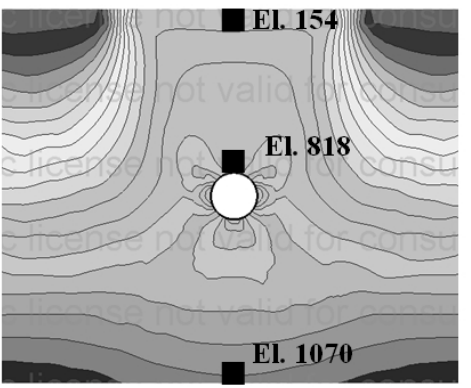

b)

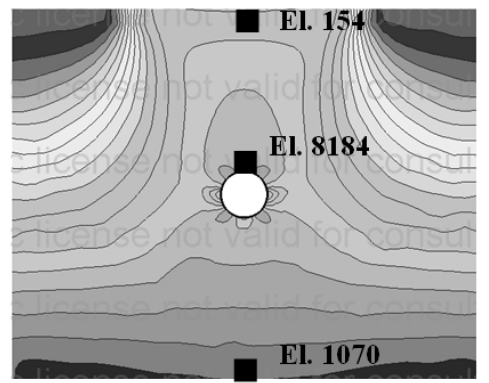

Rys. 4. Mapa pionowych naprężeń w gruncie $(t=5,0)$ : a) WARIANT 1, b) WARIANT 2

Fig. 4. Maps of the vertical stresses in soil $(t=5,0)$ : a) VARIANT 1 , b) VARIANT 2

W ramach analizy parametrycznej, wykonanej dla wszystkich wariantów modelu układu rurociąg-grunt, wyznaczono także wartości obwodowych sił normalnych $N_{x}$ i obwodowych momentów zginających $M_{\mathrm{z}}$. Przykładowo, dla WARIANTU $1(t=5,0)$ na rysunku 6 pokazano wykresy wartości tych sił i momentów zginających. Dla pozostałych wariantów charakter wykresów jest zbliżony, choć przy różnych wartościach współczynnika prekonsolidacji OCR występują wyraźne różnice w ekstremalnych wartościach $M_{\mathrm{z}}$. i $N_{x}$.

Cechami charakterystycznymi tych rozkładów są: różnoznakowość momentu zginającego na obwodzie pierścienia rurowego (dodatni moment zginający w kluczu rury i jej najniższym punkcie, ujemny - w strefach bocznych, zerowanie się momentu przy wielokrotności kąta obwodowego $\varphi \approx n \cdot 45^{0}, n=1,3,5,7$ ) oraz jednoznakowość wartości siły normalnej (dla wszystkich wartości $\varphi$ siła jest ujemna, pierścień rurowy jest ściskany na całym obwodzie).

W celu porównania wartości i rozkładu obwodowych sił normalnych $N_{x}$ i obwodowych momentów zginających $M_{z}$, wyznaczonych we wszystkich wa- 
riantach modelu układu rurociąg-grunt (dla gruntów piaszczystego i gliniastego oraz różnych wartości współczynnika prekonsolidacji OCR) wykonano zbiorcze wykresy wartości $N_{x}$ (rys. 7) i $M_{z}$ (rys. 8). Rozkład analizowanych wartości sił i momentów zginających pokazano w odniesieniu do wartości kąta $\varphi$ w zakresie $0^{0}-360^{\circ}$, odmierzanego obwodowo, zgodnie z ruchem wskazówek zegara $\left(\varphi=0^{0} \mathrm{w}\right.$ kluczu rury). Sposób odmierzania kąta $\varphi$ pokazano w schematycznie na rysunkach 7 i 8 .
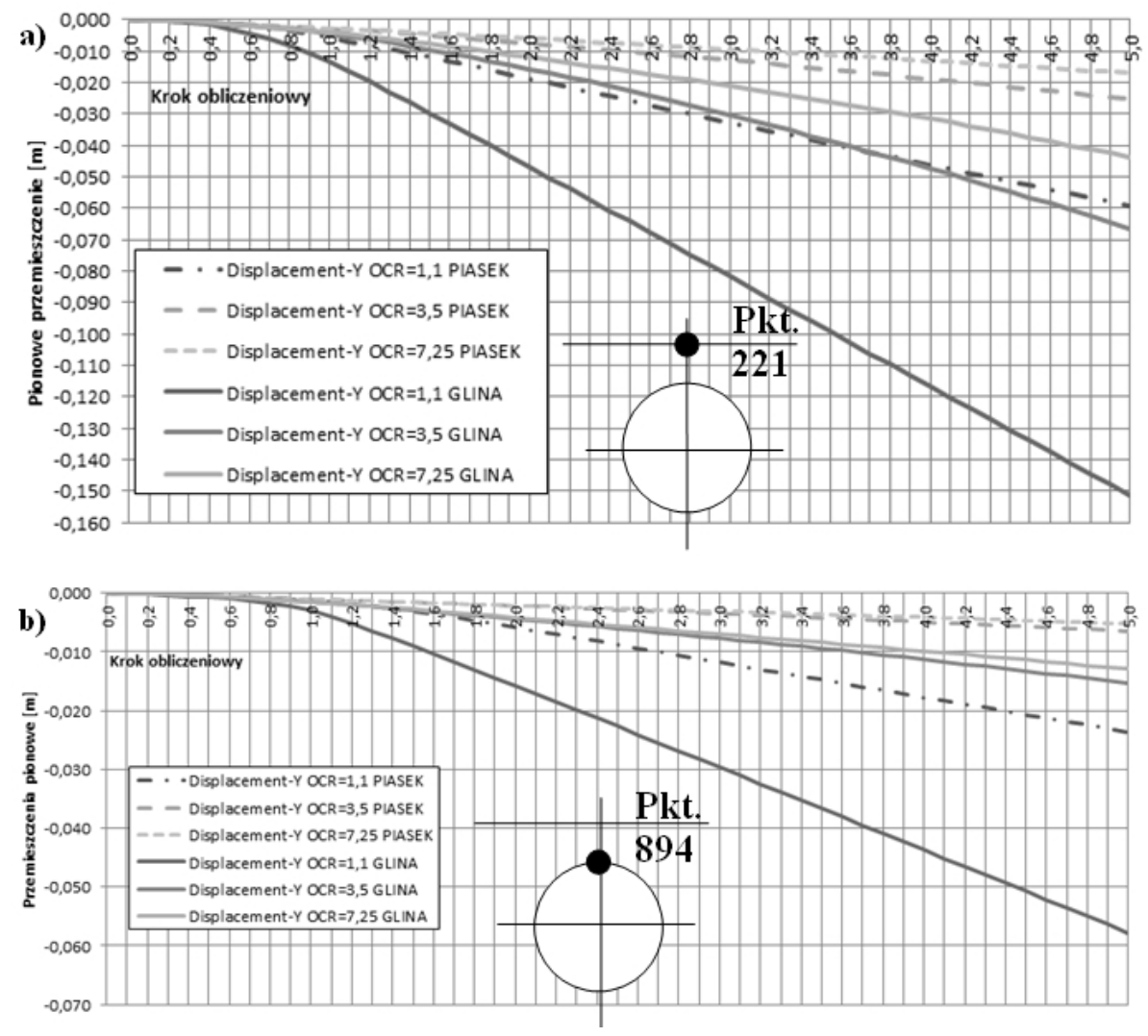

Rys. 5. Wykres pionowych przemieszczeń wybranych punktów modelu: a) punkt 221, b) punkt 894

Fig. 5. Vertical displacement diagram of selected model's points: a) point 221, b) point 894

Zmiana wartości OCR w zakresie 1,1-3,5 (WARIANTY: 1, 1a, 2, 2a) praktycznie nie wpływa na zróżnicowanie wartości obwodowych sił normalnych $N_{x}$. Ekstremalne wartości obwodowych sił normalnych $N_{x}$ dla tych wariantów wynoszą: $\sim-10 \mathrm{kN} / \mathrm{m}\left(\varphi=0^{0}\right)$ i $-19 \mathrm{kN} / \mathrm{m}\left(\varphi=90^{\circ}\right)$ (dla gruntu piaszczystego) oraz $\sim-9 \mathrm{kN} / \mathrm{m}\left(\varphi=0^{0}\right)$ i $-17 \mathrm{kN} / \mathrm{m}\left(\varphi=90^{\circ}\right)$ (dla gruntu gliniastego). W wariantach $1 \mathrm{~b}$ i $2 \mathrm{~b}$, w których OCR $=7,25$ wartości sił obwodowych sił normalnych $N_{x}$ 
wzrastają i wynoszą odpowiednio ok. $-13 \mathrm{kN} / \mathrm{m}\left(\varphi=0^{0}\right)$ i $-23 \mathrm{kN} / \mathrm{m}\left(\varphi=90^{0}\right)$ (dla gruntu piaszczystego) oraz $\sim-11 \mathrm{kN} / \mathrm{m}\left(\varphi=0^{0}\right)$ i $-20 \mathrm{kN} / \mathrm{m}\left(\varphi=90^{\circ}\right)$ (dla gruntu gliniastego).
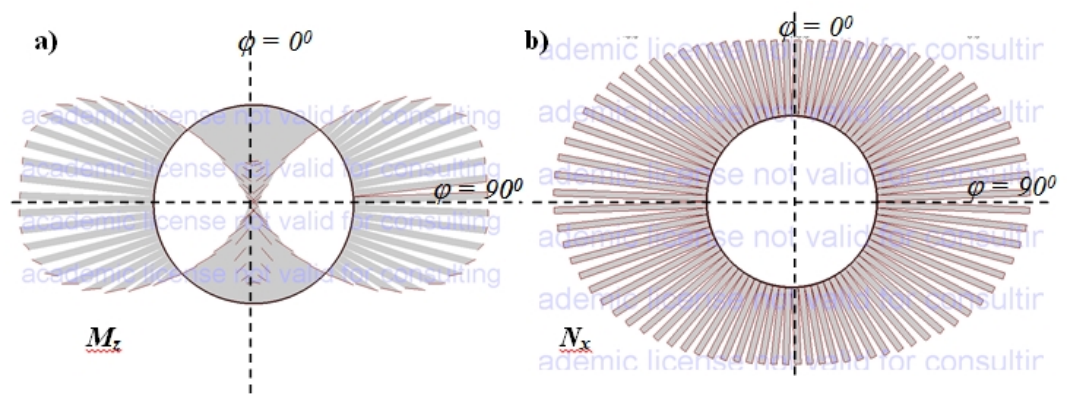

Rys. 6. Wykres obwodowych momentów zginających $M_{z}$ i sił normalnych $N_{x}$ (WARIANT 1 , $t=5,0)$

Fig. 6. Diagrams of the circumferential bending moments $M_{z}$ and normall forces $N_{x:}$ (VARIANT 1, $t=5,0)$.

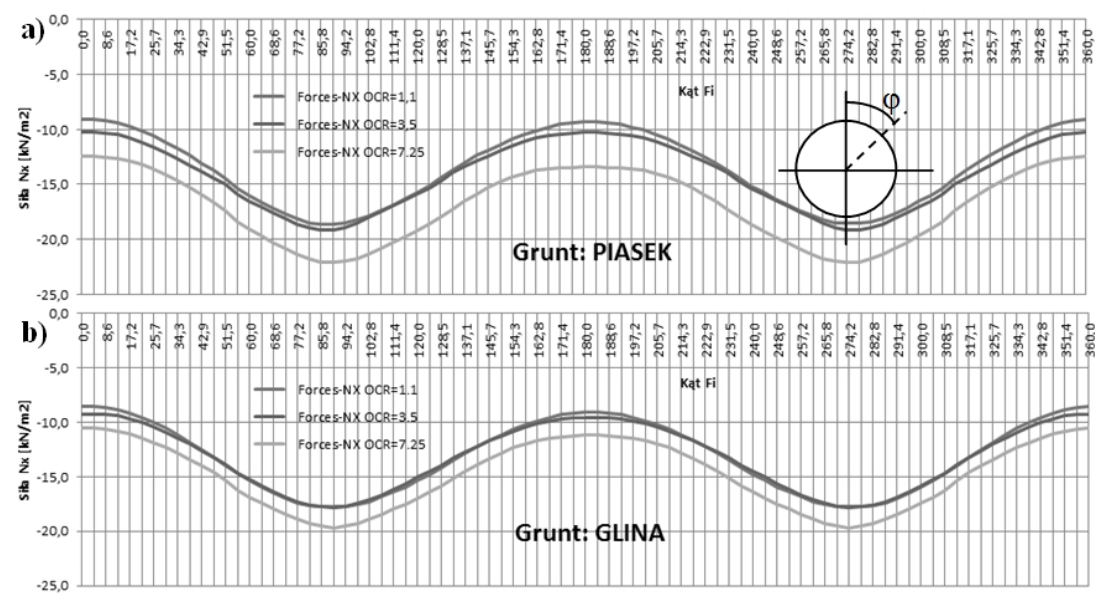

Rys. 7. Wykres obwodowych sił normalnych $N_{x}$ : a) WARIANTY: 1, 1a, 1b; b) WARIANTY: $2,2 \mathrm{a}, 2 \mathrm{~b}$

Fig. 7. Diagrams of the circumferential normall forces $N_{x}$ : a) VARIANTS: $1,1 \mathrm{a}, 1 \mathrm{~b}$; b) VARIANTS: 2, 2a, 2b

Skutki wariantowania wartości współczynnika prekonsolidacji OCR są bardziej widoczne na wykresach obwodowych momentów zginających $M_{z}$. Ekstremalne wartości $M_{z}$ w różnych wariantach analizy wynoszą:

- WARIANT 1 (grunt piaszczysty, OCR $=1,1$ ):

$+0,212 \mathrm{kNm} / \mathrm{m}\left(\varphi=0^{0}\right) ;-0,158 \mathrm{kNm} / \mathrm{m}\left(\varphi=90^{\circ}\right)$, 
- WARIANT 2 (grunt gliniasty, OCR $=1,1$ ):

$+0,315 \mathrm{kN} / \mathrm{m}\left(\varphi=0^{0}\right) ;-0,278 \mathrm{kN} / \mathrm{m}\left(\varphi=90^{\circ}\right)$,

- WARIANT 1a (grunt piaszczysty, OCR $=3,5$ ):

$+0,095 \mathrm{kNm} / \mathrm{m}\left(\varphi=0^{0}\right) ;-0,062 \mathrm{kNm} / \mathrm{m}\left(\varphi=90^{0}\right)$,

- WARIANT 2a (grunt gliniasty, OCR $=3,5$ ):

$+0,161 \mathrm{kN} / \mathrm{m}\left(\varphi=0^{0}\right) ;-0,144 \mathrm{kN} / \mathrm{m}\left(\varphi=90^{\circ}\right)$,

- WARIANT $1 \mathrm{~b}$ (grunt piaszczysty, OCR $=7,5$ ):

$+0,041 \mathrm{kNm} / \mathrm{m}\left(\varphi=0^{0}\right) ;-0,056 \mathrm{kNm} / \mathrm{m}\left(\varphi=90^{0}\right)$,

- WARIANT $2 \mathrm{~b}$ (grunt gliniasty, OCR $=7,5$ ):

$+0,108 \mathrm{kN} / \mathrm{m}\left(\varphi=0^{0}\right) ;-0,107 \mathrm{kN} / \mathrm{m}\left(\varphi=90^{\circ}\right)$.

Jak widać, wartości obwodowych momentów zginających $M_{z}$ maleją w wariantach, w których w konstytutywnym modelu gruntu wprowadzono większe wartości współczynnika prekonsolidacji OCR.

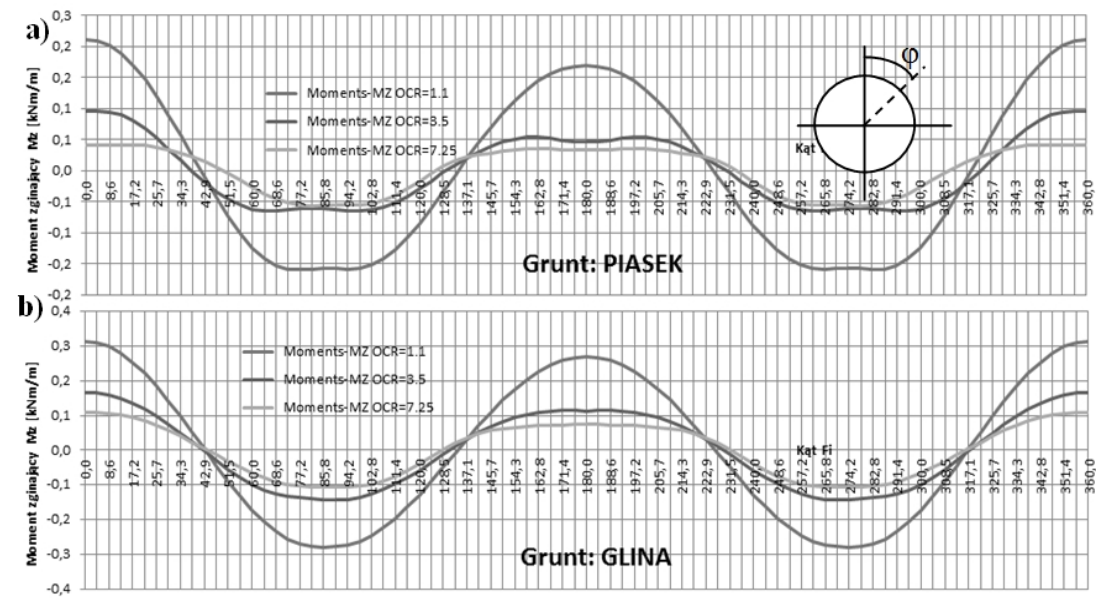

Rys. 8. Wykres obwodowych momentów zginających $M_{z}$ : a) WARIANTY: 1, 1a, 1b; b) WARIANTY: 2, 2a, 2b

Fig. 8. Diagrams of the circumferential bending moments $M_{z:}$ VARIANTS: 1, 1a, 1b; b) VARIANTS: 2, 2a, 2b

Generalnie można stwierdzić, że model Hardening Soil Small, zastosowany do opisu zachowania się gruntów w trakcie obciążania, wykazuje wrażliwość na historię obciążenia, reprezentowaną przez różne wartości współczynnika prekonsolidacji OCR.

\section{Podsumowanie}

W przypadku interakcji układu rurociąg-grunt, gdzie wyraźnie przeważa obciążenie monotonicznie zmienne, użycie modelu sprężysto-plastycznego o wzmocnieniu izotropowym Hardening Soil Small uznać można za racjonalne 
i uzasadnione. Przedstawiona numeryczna analiza 2D tego układu umożliwia oszacowanie stanu deformacji i naprężeń $\mathrm{w}$ gruncie oraz wytężenia rurociągu. Wykonana analiza parametryczna modelu HS Small (wpływ współczynnika prekonsolidacji OCR) wykazała wrażliwość tego modelu na historię obciążenia.

\section{Literatura}

[1] Atkinson J., Sallfors G.: Experimental determination of soil properties. Proc. 10 $0^{\text {th }}$ ECSMFE, vol. 3, Florence 1991.

[2] Benz T.: Small-strain stiffness of soil and its numerical conseqences. Phd, Universitst Stutgart, 2006.

[3] Bolton M. D.: The strenght and dilatancy of sands. Geotechnique, vol. 36, 1986.

[4] Gryczmański M.: Wprowadzenie do opisu sprężysto-plastycznych modeli gruntów. Polska Akademia Nauk. KILiW. IPPT, Warszawa, 1995.

[5] Kliszczewicz B.: Interakcja rurociągów o różnych sztywnościach z gruntem. Monografia nr 534. Wyd. Pol. Śl., Gliwice 2014.

[6] Pietruszczak S.: Podstawy teorii plastyczności w geomechanice. Dolnośląskie Wyd. Edukacyjne, Wrocław 2015.

[7] Schanz T.: Zur Modellierung des mechanischen Verhaltens von Reinbungsmaterialien. Mat. Inst. für Geotechnik 44. Universitat Stuttgart, 1998.

[8] Truty A.: Sztywność gruntów w zakresie małych odkształceń. Aspekty modelowania numerycznego. Czasopismo Techniczne, z. 3, 2008.

[9] Truty A., Obrzud R.: The Hardening Soil Model - a practical guidebook. Zace Services Ltd, Software engineering. Lausanne 2011.

\section{APPLICATION OF HARDENING SOIL SMALL MODEL IN THE PIPELINE-SOIL SYSTEM NUMERICAL ANALYSIS}

\section{S u m m a r y}

In the paper the basic information about elasto-plastic constitutive soil models is presented. In particular, the elasto-plastic Hardening Soil Small model with isotropic hardening was taken into consideration and used in 2D numerical analysis of pipelines-soil system. The sensitivity of HSS model was studied within parametric analysis (impact of over-consolidated ratio OCR)

Keywords: MES, interaction pipeline-soil, constitutive soil model

DOI: $10.7862 / \mathrm{rb} .2016 .160$

Przestano do redakcji: 01.05.2016 $r$.

Przyjęto do druku: 28.06.2016 r. 